\title{
Research on Emotional Intelligence and its Impact on Organizational Commitment towards Women Employees Working in Bpo Companies in Chennai
}

\author{
M. Theboral Victoriya, R. Angayarkanni
}

\begin{abstract}
Compared toward previous century, today's world is experiencing advancement in varied fields. Due to this change several organization have came forward to sort out the challenges that rise at the initial level. Modern information technology except more innovation from the employees point of view and make them pressure free and highly productive in their workplace. This is more evident in BPO and IT sector which has to deal with complex challenges both in business and human behavior. This study aims at analyzing the relationship between employees with high Emotional Intelligence and its impacts on organizational commitment. The data had been collected from BPO employees and sample size is 150 women employees and statistical tools and convenient sampling method were used to analyze the study for inference. The study finally suggested some strategies to be followed in IT sector and recommend women employees to upgrade their work performance
\end{abstract}

Keywords: Emotional Intelligence, Women employees, BPO, Organizational Commitment etc.,

\section{INTRODUCTION}

In this new millennium era business has been mainly characterized by several competitive environment and global demands. Extension of several service sectors has given a platform to more advancement in modern technology. In this situation Human Resource Management are engaged in several initiatives in order to fulfill the expectation of organizational needs and wants in the daily scenario. Employees are also.

This is often leads to stress of the employees with work pressure to increase the emotional needs in higher level. This is finally leads to commit employees to experience pressure in both physical as well as psychological level. Because the employees occupied under BPO are constantly worked with higher expectation, speedy delivery, customer satisfaction and organization demands. Moreover employees are suffered with Rotating shift. Overtime of work, fatigue, work overloads and various issues etc. There it is mainly impacts the lifestyle of the employees and organizational performance in several ways such as poor quality of work, employee turnover, absenteeism, less commitment, work imbalance, work and life stress, burnout etc. In order to

Revised Version Manuscript Received on September 16, 2019.

M. Theboral Victoriya, Ph.D. Research Scholar, Dept of Commerce, Science and Humanities, SRM Institute of Science and Technology, Kattankulathur, Tamil Nadu, India.

Dr. R. Angayarkanni, Associate Professor \& Research Supervisor, Department of Commerce, Faculty of Science and Humanities, SRM Institute of Science and Technology, Kattankulathur, Tamil Nadu, India reduce such situation the Modern technology has to be filled with satisfaction and immediate attention has to be given especially in IT sector. For example Emotional intelligence will be much helpful to reduce the workplace problem and upgrade the organization commitment in higher level.

More consequently various researches has concentrated on life or work satisfaction among the employees in IT sector. But very limited studies were concentrated on emotions and commitments amongst women employees, so this empirical analysis will be much helpful to analyze the situation of women employees in BPO sector in Chennai city.

\section{OBJECTIVES OF THE STUDY}

In order to confirm the statement of the problem. Several objectives of the study has been listed out

1. To analyse the Emotional intelligence followed by women employees in BPO sector.

2. To identify the factor influencing emotional intelligence among women employees.

3. To study the impact of emotional intelligence and organizational commitment of the respondents working in IT sector.

\section{IGNIFICANCE OF STUDY}

Generally IT industry is well known for developing the nation with significant innovation or techniques, because it mainly increase the National economy through organizational economy. It does not mean that IT industry is not only for the economy and cost saving, it also upgrade the talented human resources with the use of Modern techniques and tools. In connection with IT and ITES industry. The industry also linked with business processing outsourcing which mainly concentrate on customer care executives, services to the customer telemarketing, Medical and legal transaction, back office and front office services, E-learning process etc.

Similarly every organization mainly aims to increase the productivity and profit with the support of man power certainly job skills and competent employee talents are one of the significant element which helps the organization to achieve their target. Therefore management need to provide a
Blue Eyes Intelligence Engineering \& Sciences Publication 
proper platform to all the employees with best possible actions, trainings and skills etc. Most importantly, BPO sector are committed with crumbling trust Jarring uncertainly, issues between manage and coworkers, Cost consciousness, pool working environment. Therefore in order to reduce such situation emotional intelligence act as the key role for reducing the burden of employees in sustainable level with overcoming several problems and challenges. Emotional intelligence mainly creates a positive outcomes and improves their lifestyle with much healthier, less stressed and more product in their work. The research has been directed to understand the link between the Emotional Intelligence and Organizational Commitment of the woman employees in the BPO organizational environment. The study is significant to two areas, the dimensions, and level of EI and its impact on OC.

\section{SCOPE OF THE STUDY}

The current study will outline the situation prevailing in IT and BPO sector specifically focusing on women employees. It mainly identify the focal point which is associated with EI among the women employees in BPO sector. The study also highlights the impact of the two study variable with women employees in BPO sectors. It will be more useful for the further research works associated with work pressure and challenges among women employees in BPO sector. This study is restricted to the perception of employees working in selected BPO companies in Chennai. The choice of the study is confined within the Chennai district. This study is conducted to suggest some measures to improve the working environment for effective management of Emotional Intelligence and improve the Organizational Commitment towards the work and organization.

\section{REVIEW OF LITERATURE}

Abraham (2000) in their study were concentrated on comparing the relationship and commitment in the organizational level. The study finally explored that employees were possessing towards higher emotional intelligence on the other Research Abraham (2004) have clearly identified that EI is positively associated with organizational commitment in the increased level.

Petrides and Furham (2006) made an attempt on research and delivered that there relationship between emotional intelligence and organizational commitment. It was clearly stated that higher EI are mainly associated with lower degrees of stress and higher level of organizational commitment.

Salami (2208) made an investigation on study related variables among the industrial workers in Nigeria. Finally the study predicted that there is a significant relationship between Emotional Intelligence and organizational differences. The study also suggested the management to concentrated on the main factors of emotional intelligence in efficient manner.

Sarboland (2012) in his study clearly mentioned the significant relationship between Emotional Intelligence and organization performance with the support of Tax officers in Ardabil Province, on the another research, Fard and Khan (2014) made an investigation among Municipality employees in order to listed out the main factor linked with emotional intelligence such as self-awareness, self-control, self-motivation, social consciousness and skill etc.

\section{RESEARCH METHODOLOGY}

The detailed methodology of the research has been described based on research design, sampling design, data collection method and analysis, which are given in the following table:

TABLE 1.1

Research Methodology

\begin{tabular}{|l|l|}
\hline Research Method & Descriptive and Analytical Research \\
\hline Study Design & Exploratory Research \\
\hline Population & $\begin{array}{l}\text { Woman Employees of BPO } \\
\text { Companies in Chennai }\end{array}$ \\
\hline Sample size & 150 \\
\hline Sampling Area & Chennai \\
\hline Sampling Method & $\begin{array}{l}\text { Non - Probability sampling - } \\
\text { Convenience sampling }\end{array}$ \\
\hline Data type & $\begin{array}{l}\text { Primary Majority of the data) and } \\
\text { Secondary Data }\end{array}$ \\
\hline $\begin{array}{l}\text { Sources of Primary } \\
\text { Data }\end{array}$ & $\begin{array}{l}\text { Questionnaire and Personal } \\
\text { Interview }\end{array}$ \\
\hline $\begin{array}{l}\text { Sources of } \\
\text { Secondary Data }\end{array}$ & $\begin{array}{l}\text { Newspapers, Journals, Magazines, } \\
\text { Reports, books, research articles, } \\
\text { internet, etc. }\end{array}$ \\
\hline $\begin{array}{l}\text { Research } \\
\text { instrument }\end{array}$ & Structured Questionnaire \\
\hline $\begin{array}{l}\text { Statistical Tools } \\
\text { used }\end{array}$ & $\begin{array}{l}\text { Descriptive \& Inferential Statistical } \\
\text { tools }\end{array}$ \\
\hline $\begin{array}{l}\text { Period of data } \\
\text { collection }\end{array}$ & April 2018 to May 2018 \\
\hline $\begin{array}{l}\text { Software used for } \\
\text { analysis }\end{array}$ & \begin{tabular}{l} 
SPSS (Version 2.0) \\
\hline
\end{tabular} \\
\hline
\end{tabular}

\section{DATA ANALYSIS AND DISCUSSION \& RESULTS}

Data analysis has been made through various statistical tools to understand the outcomes regarding the purposes and assumption. To examine and give the appropriate interpretation of data diverse statistical tools (descriptive as well as inferential) are used.

\section{Demographic \& Job Profile}


TABLE 1.2

Demographic \& Job Profile

$($ Sample Size $=150)$

\begin{tabular}{|c|c|c|c|}
\hline VARIABLES & OPTIONS & FREQUENCIES & $(\%)$ \\
\hline Age & $\begin{array}{l}20-30 \text { Years } \\
31 \text { - } 52 \text { Years }\end{array}$ & $\begin{array}{ll}\text { Open } & \text { ended } \\
\text { Question } & \text { (Scale } \\
\text { Variable) } & \end{array}$ & $\begin{array}{l}52.00 \\
48.00\end{array}$ \\
\hline $\begin{array}{l}\text { Marital } \\
\text { Status }\end{array}$ & $\begin{array}{l}\text { Married } \\
\text { Unmarried }\end{array}$ & $\begin{array}{l}59 \\
91\end{array}$ & $\begin{array}{l}39.30 \\
60.70\end{array}$ \\
\hline Qualification & $\begin{array}{l}\text { School/Diploma } \\
\text { UG / PG } \\
\text { Professional }\end{array}$ & $\begin{array}{l}33 \\
97 \\
20\end{array}$ & $\begin{array}{l}22.00 \\
64.70 \\
13.30\end{array}$ \\
\hline $\begin{array}{l}\text { Monthly } \\
\text { Salary (INR) }\end{array}$ & $\begin{array}{l}\text { Upto Rs.25,000 } \\
\text { Rs.25,001 - } \\
\text { Rs.50,000 } \\
\text { Above } \\
\text { Rs.50,000 }\end{array}$ & $\begin{array}{l}61 \\
38 \\
51\end{array}$ & $\begin{array}{l}40.70 \\
25.30 \\
34.00\end{array}$ \\
\hline $\begin{array}{l}\text { Job } \\
\text { Experience }\end{array}$ & $\begin{array}{l}1 \text { - } 3 \text { Years } \\
\text { 3-6 Years } \\
\text { Above } 6 \text { Years }\end{array}$ & $\begin{array}{l}75 \\
62 \\
13\end{array}$ & $\begin{array}{l}50.00 \\
41.30 \\
8.70\end{array}$ \\
\hline $\begin{array}{l}\text { Working } \\
\text { Shift }\end{array}$ & $\begin{array}{l}\text { General / Day } \\
\text { shift } \\
\text { Night shift } \\
\text { Rotating Shift }\end{array}$ & $\begin{array}{l}35 \\
43 \\
72\end{array}$ & $\begin{array}{l}23.30 \\
28.70 \\
48.00\end{array}$ \\
\hline
\end{tabular}

Source: Primary Data

\section{Interpretation}

From the above table, it is inferred that the range of Age of the respondents is 20 to 52 Years. $52 \%$ of the respondents belong to the age group of $20-30$ Years and the remaining $48 \%$ of them belong to the age group of $31-52$ years. It is inferred that unmarried respondents $(60.70 \%, 91)$ are more than married respondents $(39.30 \%, 59)$. In terms of Qualification of the respondents, 64.70\% (97) of them are UG/PGs followed by School level/Diploma education (22\%, 33 ) and remaining $13.30 \%$ of them have Professional qualification. In terms of Monthly Salary, the majority of the respondents $(40.70 \%, 61)$ are earning up to Rs.25,000. 50\% (75) of the respondents have $1-3$ years' of job experience. $48 \%$ (72) of them are working in Rotating Shifts followed by
Night Shifts $(28.70 \%, 43)$ and General/Day Shift $(23.30 \%$, $35)$.

\section{Dimensions Of Emotional Intelligence}

TABLE 1.3

Dimensions Of Emotional Intelligence Descriptive Statistics

\begin{tabular}{|l|l|l|l|}
\hline VARIABLES & N & Mean & SD \\
\hline Appraisal of Self-Emotion & 150 & 19.37 & 3.300 \\
\hline $\begin{array}{l}\text { Appraisal of Other's } \\
\text { Emotion }\end{array}$ & 150 & 19.83 & 3.429 \\
\hline Regulation of Emotion & 150 & 19.66 & 3.287 \\
\hline Usage of Emotion & 150 & 19.90 & 3.381 \\
\hline $\begin{array}{l}\text { Overall Emotional } \\
\text { Intelligence Score }\end{array}$ & $\mathbf{1 5 0}$ & $\mathbf{7 8 . 7 5}$ & $\mathbf{1 2 . 5 5 6}$ \\
\hline
\end{tabular}

Source: Primary Data

\section{Interpretation}

Twenty Questions relating to four dimensions of Emotional Intelligence (5 questions for each dimension) based on five-point Likert scale, (Strongly Disagree (1) to Strongly Agree (5)) were given in the questionnaire. BPO woman employees' perception of these dimensions is measured by using a descriptive statistical tool (Mean Analysis). From the above table, it is concluded that the woman employees perception on Usage of Emotion $(\mathrm{M}=$ 19.90) is more than others and on Appraisal of Self-Emotion $(\mathrm{M}=19.37)$ is lesser than others. It is also inferred that the Employees' Perception on four dimensions of Emotional Intelligence is above the average level since the all mean values are above $19(76 \%)$ out of 25 . The Overall Mean Score of the Emotional Intelligence of BPO Woman Employees in Chennai is 78.75 which is above $78 \%$ (78.75 / $100 \times 100=78.75 \%$ ). This indicates that the Woman Employees' Perception of Emotional Intelligence in BPO Companies is above $78 \%$.

\section{Independent Sample 'T' Test-Analysis}

$H_{0}: \quad$ There is no significant difference between the Married and Unmarried respondents with respect to the dimensions of Emotional Intelligence. 
Research on Emotional Intelligence and its Impact on Organizational Commitment Towards Women Employees Working in Bpo Companies in Chennai

TABLE 1.4

Marital status - emotional intelligence

\begin{tabular}{|c|c|c|c|c|c|c|c|c|}
\hline \multirow{3}{*}{ VARIABLES } & \multicolumn{6}{|c|}{ MARITAL STATUS } & \multirow{3}{*}{$\mathrm{t}$ - value } & \multirow{3}{*}{$\begin{array}{c}\text { p - } \\
\text { value }\end{array}$} \\
\hline & \multicolumn{3}{|c|}{ MARRIED } & \multicolumn{3}{|c|}{ UNMARRIED } & & \\
\hline & $\mathbf{N}$ & Mean & SD & $\mathbf{N}$ & Mean & SD & & \\
\hline Appraisal of Self-Emotion & 82 & 18.95 & 3.712 & 68 & 18.30 & 3.361 & 3.261 & $0.036^{*}$ \\
\hline $\begin{array}{l}\text { Appraisal of Other's } \\
\text { Emotion }\end{array}$ & 82 & 19.83 & 3.217 & 68 & 18.92 & 3.788 & 2.875 & $0.019 *$ \\
\hline Regulation of Emotion & 82 & 20.05 & 3.231 & 68 & 19.56 & 2.754 & 2.632 & $0.023 *$ \\
\hline Usage of Emotion & 82 & 20.32 & 3.125 & 68 & 19.35 & 3.147 & 3.987 & $\begin{array}{l}0.007 * \\
*\end{array}$ \\
\hline $\begin{array}{l}\text { DIMENSIONS OF } \\
\text { EMOTIONAL } \\
\text { INTELLIGENCE }\end{array}$ & 82 & 79.15 & 12.12 & 68 & 76.13 & 12.95 & 3.995 & $\begin{array}{c}0.004 * \\
*\end{array}$ \\
\hline
\end{tabular}

Source: Primary Data (** 1\% Level of Significance, * 5\% Level of Significance)

Interpretation

An independent-samples t-test was conducted to compare the difference between the Married and Unmarried respondents concerning four dimensions of Emotional Intelligence. As the $\mathrm{P}$ values are lesser than Sig. Value (0.01 and 0.05) in all the cases, the Null Hypotheses are rejected.

Based on the mean scores, we can say that the Overall Mean Score of Dimensions of Emotional Intelligence for Married respondents $(\mathrm{M}=79.15)$ is more than Unmarried respondents $(M=76.13)$. This denotes that the Married respondents have more perception on four dimensions of Emotional Intelligence than the Unmarried respondents. The married respondents have more perception on Usage of Emotion ( $M=20.32)$ when compared with others and Unmarried respondents have more perception on Regulation of Emotion $(\mathrm{M}=19.56)$ when compared with others. Both married and unmarried respondents have a lesser perception on Appraisal of Self-Emotion when compared with others. It is concluded that there is a statistically significant difference between the Married and Unmarried respondents concerning Emotional Intelligence.

\section{Correlation Analysis}

$H_{0}$ : There is no significant relationship between the Dimensions of Emotional Intelligence and Emotional Intelligence

TABLE 1.5

Dimensions Of Emotional Intelligence - Emotional Intelligence

\begin{tabular}{|c|c|c|c|c|c|c|}
\hline \multirow[b]{2}{*}{ VARIABLES } & \multirow[b]{2}{*}{$\mathbf{N}$} & \multirow{2}{*}{$\begin{array}{l}\text { 'r' } \\
\text { VALUE }\end{array}$} & \multirow{2}{*}{$\begin{array}{l}P \\
\text { VALUE }\end{array}$} & \multirow{2}{*}{$\begin{array}{l}\text { RELATI } \\
\text { ON } \\
\text { SHIP }\end{array}$} & \multicolumn{2}{|l|}{ REMARKS } \\
\hline & & & & & $\begin{array}{l}\text { SIGNIFICA } \\
\text { NT }\end{array}$ & RESULT \\
\hline $\begin{array}{lr}\text { Appraisal } & \text { of } \\
\text { Self-Emotion } & - \\
\text { Emotional } & \\
\text { Intelligence } & \\
\end{array}$ & 150 & $0.886 * *$ & 0.000 & Positive & Significant & Rejected \\
\hline $\begin{array}{l}\text { Appraisal of } \\
\text { Other's Emotion - } \\
\text { Emotional } \\
\text { Intelligence }\end{array}$ & 150 & $0.831 * *$ & 0.000 & Positive & Significant & Rejected \\
\hline $\begin{array}{ll}\text { Regulation } & \text { of } \\
\text { Emotion } & - \\
\text { Emotional } & \\
\text { Intelligence } & \end{array}$ & 150 & $0.937 * *$ & 0.000 & Positive & Significant & Rejected \\
\hline $\begin{array}{l}\text { Usage of Emotion - } \\
\text { Emotional } \\
\text { Intelligence }\end{array}$ & 150 & $0.949 * *$ & 0.000 & Positive & Significant & Rejected \\
\hline
\end{tabular}




\section{Interpretation}

The $\mathrm{P}$ value is lesser than Sig. value $(0.01)$ in all the above statements, hence the Null hypotheses are rejected and Alternate hypotheses are accepted. There are high positive correlations between the Appraisal of Self-Emotion, Appraisal of Other's Emotion, Regulation of Emotion and Usage of Emotion and Emotional Intelligence of employees of BPO Companies. The relationships between them are highly significant.

Out of four dimensions of emotional intelligence, the relationship between Usage of Emotion and Emotional Intelligence $(r=0.949)$ is more than others and Appraisal of Other's Emotion has a lesser relationship with Emotional Intelligence $(r=0.831)$ than others. It is inferred that Usage of Emotion has a strong influence on the Emotional Intelligence of employees. Hence, there is a significant relationship between the Dimensions of Emotional Intelligence and Emotional Intelligence of employees of BPO Companies.

$H_{0}$ : There is no significant relationship between the Components of Emotional Intelligence and Organizational Commitment of employees of BPO Companies.

A Pearson product-moment correlation was run to determine the relationship between the Appraisal of Self-Emotion, Appraisal of Other's Emotion, Regulation of Emotion and Usage of Emotion and Organizational Commitment of employees of BPO Companies.

TABLE 1.6

Dimensions Of Emotional Intelligence - Organisational Commitment

\begin{tabular}{|c|c|c|c|c|c|c|}
\hline \multirow[b]{2}{*}{ VARIABLES } & \multirow[b]{2}{*}{$\mathbf{N}$} & \multirow{2}{*}{$\begin{array}{l}\text { 'r' } \\
\text { VALUE }\end{array}$} & \multirow[b]{2}{*}{$P$ - VALUE } & \multirow{2}{*}{$\begin{array}{l}\text { RELATION } \\
\text { SHIP }\end{array}$} & \multicolumn{2}{|l|}{ REMARKS } \\
\hline & & & & & $\begin{array}{l}\text { SIGNIFICA } \\
\text { NT }\end{array}$ & RESULT \\
\hline $\begin{array}{lr}\text { Appraisal } & \text { of } \\
\text { Self-Emotion } & - \\
\text { Organizational } \\
\text { Commitment }\end{array}$ & 150 & $0.906 * *$ & 0.000 & Positive & Significant & REJECTED \\
\hline $\begin{array}{lr}\text { Appraisal of } & \text { Other's } \\
\text { Emotion } & - \\
\text { Organizational } \\
\text { Commitment }\end{array}$ & 150 & $0.848 * *$ & 0.000 & Positive & Significant & REJECTED \\
\hline $\begin{array}{l}\text { Regulation of Emotion - } \\
\text { Organizational } \\
\text { Commitment }\end{array}$ & 150 & $0.911 * *$ & 0.000 & Positive & Significant & REJECTED \\
\hline $\begin{array}{l}\text { Usage of Emotion - } \\
\text { Organizational } \\
\text { Commitment }\end{array}$ & 100 & $0.915 * *$ & 0.000 & Positive & Significant & REJECTED \\
\hline
\end{tabular}

** Significant at the 0.01 level (2-tailed).

\section{Interpretation}

As the P value is lesser than Sig. Value (0.01) in all the above cases, the Null Hypotheses are rejected. There are high positive correlations between the Appraisal of Self-Emotion, Appraisal of Other's Emotion, Regulation of Emotion and Usage of Emotion and Organizational Commitment of woman employees of BPO Companies.

Out of four dimensions of Emotional Intelligence, the relationship between Usage of Emotion and Stress Management $(r=0.915)$ is more than others. It is inferred that Usage of Emotion has a strong impact on Organizational Commitment of employees of BPO Companies. It indicates that those who effectively using their emotions have more organizational commitment. Hence, there is a significant relationship between the Appraisal of Self-Emotion, Appraisal of Other's Emotion, Regulation of Emotion and Usage of Emotion and Organizational Commitment of woman employees of BPO Companies.

\section{Multiple Regression}

This Analysis was conducted to determine the best linear combination of Appraisal of Self-Emotion, Appraisal of Other's Emotion, Regulation of Emotion and Usage of Emotion for predicting Organizational Commitment of woman employees working in BPO Companies.

This combination of three out of all variables significantly predicts the dependent variable i.e., Organizational Commitment, $F(4,145)=408.701, p=.000$ which is lesser than .001 (Sig. Value 2-tailed) and Adjusted R Square = 0.916 .

Out of independent variables, Usage of Emotion (0.421) is the strongest influencing factor which predicting dependent variable. The beta weights recommend that the usage of emotion only contribute most $(0.421$ or $42 \%)$ to predict Organizational Commitment. Appraisal of Other's Emotion contributes to Organizational Commitment (0.206) lesser than others and Regulation of Emotion (0.116) does not predict Organizational Commitment significantly. 


\section{Research on Emotional Intelligence and its Impact on Organizational Commitment Towards Women Employees Working in Bpo Companies in Chennai}

\section{LIMITATIONS AND DIRECTION FOR FUTURE STUDIES}

Only about 150 employees working in BPO companies were used as sample in this research and therefore cannot be considered as an extensive research. The study is limited to employees working in and around Chennai and is not a pan state or pan India research. Further research can concentrate on ascertaining the influence of Emotional Intelligence on organizational commitment on a district level or state wide. Future researcher may also concentrates other variables like stress, work life balance, career development etc. This study is limited to women employees working in BPO companies, i.e., IT enabled services in and around Chennai. Based on this fact, further comparative studies can also be carried out on different IT sectors on varied geographical locations.

\section{DISCUSSION AND CONCLUSION}

Significant interest has been generated over the past decade in the academic and HR community world-wide to study Emotional Intelligence. Interestingly emotional intelligence is not given its due importance while designing skill development program. Research has proven that properly managed emotion can drive loyalty and trust towards work commitment. Study has proven positive relationship between organizational commitment and emotional intelligence. It is also noted employee with high emotional intelligence do better when compare to employee with low emotional intelligence in an organizational setup. From the present study revealed that usage of emotional intelligence improve the commitment of employees towards their work and organization. It is suggested that it would be beneficial in the long run to hire employees who have high degree of emotional intelligence to better impact the organizational structure.

\section{REFERENCES}

1 Abraham, R. (2000). The role of job control as a moderator of emotional dissonance and emotional intelligence-outcome relationships. Journal of Psychology, 134 (2), 169.

2 Abraham, R. (2004). Emotional competence as antecedent to performance: A contingency framework. Genetic, Social \& General Psychology Monographs, 130 (2), 117-143.

3 Alikhani, M., Aghili, R., Arzhang, N.,Yadolahi, A., \& Shafahi, S. (2015). Examining the relationship between emotional intelligence, organizational commitment and job satisfaction among managers. GMP Review, 16, 272-276.

4 Allen, N. J., \& Meyer, J. P. (1990). The measurement and antecedents of affective, continuance and normative commitment to the organization. Journal of Occupational Psychology, 63, 1-18.

5 Fard, M. S., \& Khan, N. I. (2014). Examine the relationship between the elements of emotional intelligence and organizational commitment of employees (the Employee's Municipality of 5th region Tehran). WALIA Journal, 30(S1), 346-349.

6 Goleman, D. (1995). Emotional Intelligence: Why it can matter more than IQ. New York: Bantam.

7 Goleman, D. (1998). Examining the Relevance of Emotional Intelligence and Organizational Commitment among Employees of Small and Medium Enterprise in
Private Sector. International Journal of Business and Management. 6 (12), 180-194.

8 https://www.ibef.org/industry/information-technology-in dia.aspx

9 Mayer, J.D. and Salovey, P. (1990). Emotional Intelligence. Imagination, cognition and personality, 9, 185-211.

10 Mayer, J.D., \& Salovey, P. (1997). What is emotional intelligence? In P. Salovey \& D. J. Sluyter (Eds.), Emotional development and emotional intelligence. New York: Basic Books.

11 Nikolaou, I., \& Tsaousis, I. (2005). Emotional intelligence in the workplace: exploring its effects on occupational stress and organizational commitment. The International Journal of Organizational Analysis, 10, 327-342.

12 Petrides, K. V., \& Furnham, A. (2006). The Role of Trait Emotional Intelligence in a Gender-Specific Model of Organizational Variables. Journal of Applied Social Psychology, 36(2), 552-569.

13 Porter, L. W., Steers, R. M., Mowday, R. T., \& Boulian, P. V. (1974). Organizational commitment, job satisfaction and turnover among psychiatric technicians. Journal of Applied Psychology, 59, 603-609.

14 Salami O. Salami. (2008). Demographic and Psychological Factors Predicting organizational Commitment among Industrial Workers. Anthropologist, 10(1), 31-38

15 Sarboland, K. (2012). Assessment of the relationship between emotional intelligence and organizational commitment of employees: A case study of tax affairs offices, Iran. Journal of Basic and Applied Scientific Research, 2(5), 5164-5168.

16 Shafiq, M., \& Rana, A. R. (2016). Relationship of emotional intelligence to organizational commitment of college teachers in Pakistan. Eurasian Journal of Educational Research, 62, 1-14.

17 Wong, C. S., \& Law, K. S. (2002). The effects of leader and follower emotional intelligence on performance and attitude: An exploratory study. The Leadership Quarterly, 13 (3), 243-274. 